\title{
Application of Rasch Measurement Model in Establishing Roles Hierarchy for Malaysian Building Surveying Graduates
}

\author{
SITI HAMIDAH HUSAIN ${ }^{1}$, AFIFUDDIN HUSAIRI HUSSAIN ${ }^{2}$, ADI IRFAN CHE ANI ${ }^{3,4}$, \\ HARYANTI MOHD AFFANDI ${ }^{4}$, HASNIZAN AKSAH $^{5}$
}

\author{
${ }^{1}$ School of Housing, Building and Planning, Universiti Sains Malaysia, 11800, Penang, MALAYSIA \\ ${ }^{2}$ School of Liberal Studies, Universiti Kebangsaan Malaysia, 43600 Bangi, Selangor, MALAYSIA \\ ${ }^{3}$ Department of Architecture and Built Environment, Faculty of Engineering and Built Environment, \\ Universiti Kebangsaan Malaysia, 43600 Bangi, Selangor, MALAYSIA \\ ${ }^{4}$ Centre for Engineering Education Research, Faculty of Engineering and Built Environment, \\ Universiti Kebangsaan Malaysia, 43600 Bangi, Selangor, MALAYSIA \\ ${ }^{5}$ Centre of Studies for Building Surveying, Faculty of Architecture, Planning and Surveying, \\ Universiti Teknologi MARA, 40450 Shah Alam, Selangor, MALAYSIA
}

\begin{abstract}
Despite the rising demand for the building surveying services in the current market, the function of this profession is generally still misunderstood. Hence, this paper attempts to identify the hierarchy and potential roles that can be offered by building surveying graduates in order to provide the acceptable roles in the Malaysian construction industry. A quantitative research approach has been adopted to achieve this study's objective with close-ended questionnaires have been developed and administered to 136 professional building surveyors who are registered with the Building Surveying Division, Royal Institution of Surveyor Malaysia. The retrieved data were analysed using the IBM SPSS Statistic for the respondents' demographic data and the Rasch measurement model that applied the Winsteps version 3.70 software in order to analyse the data on reliability, item fit, and item measure for roles hierarchy. The result of the study shows that the roles hierarchy consisted of 29 essential tasks a graduate should deal with in order to thrive in the labour market after graduation. Correspondingly, building maintenance and conservation, building control administration, building inspection, risk management and building audit, building works and quality, and building insurance are the essential roles there are based on the hierarchy level that has been extracted by the six components. This study contributes to the body of knowledge in the Malaysia context, in particular for the general international building surveying community as it reveals a roles hierarchy that graduates are required to perform, and where it will provide awareness on the existence of the building surveying vocation among other the non-allied construction professionals in Malaysia.
\end{abstract}

Key-Words: - Building Surveying graduates, Building Surveyors, Roles hierarchy, Malaysian construction industry, Rasch Measurement Model.

Received: April 9, 2021. Revised: November 8, 2021. Accepted: December 5, 2021. Published: January 7, 2022.

\section{Introduction}

Over the past decades, the construction industry has been the substantial driver of growth of Malaysia's economy and development. The present-day construction industry provides significant employment opportunities for graduates particularly in engineering, architecture, planning, and surveying [1]. However, due to the high expectation of employers and the steep challenges of job nature, most of the graduate building surveyors are experiencing inadequate employment opportunities [2]. Correspondingly, the ability to perform building inspection becomes one of the fundamental competence requirements for building surveyors in performing their duties and services. Building inspection primarily involves on-site work and the preparation of a report which requires the skill in identifying defects and a familiarity with reporting procedures [3].

Contrary to international practices, the building surveyor profession offers a variety of services in the building environment fields, namely building pathology, design, project management, building surveys, property management, and contract administration [4]. The services will become an increasingly important part of service in the property and construction industry. Based on the 
worldwide practice, a generation of those who are in the building surveying (BS) profession has grown from an off-shoot of a general practice surveying to a professional group of 28,000 members worldwide [5]. This rapid and spectacular growth, internationally and locally, proves the increasing importance of the BS role in the construction industry and built environment respectively. A study by [6] reports that there is a positive growth of the BS vocation in Malaysia. The current demands for higher-quality buildings, for example, have heightened the need for BS services and roles in the construction industry.

Yet, the awareness level of the significance of BS services and roles in Malaysia is still comparatively low, misunderstood, and overlooked by other professionals and the general public [2][7]. Most of the general public are not informed about the function of the building surveyors and their contribution in the construction industry [7]. Such a lack of awareness has caused the neglect of available high-quality services that can be offered by BS practitioners. In another recent article, [2] mention that the knowledge on BS is still low because of the lack of information about the profession, which is attributed to the problems of public recognition, deficient understanding of the surveyor's skills, and fewer job opportunities.

These factors of deficiencies have contributed to the delay in the endorsement of the BS Act in Malaysia. The study by [2] has also suggested that the BS practitioners modify their role to suit the requirements of the local and international process of practice. Therefore, before dealing with the international requirements and demands, which widely differ from the local practice, the researchers have decided to deal with the local issues first, by establishing this professional's role as is demanded by the local market. In view of this, further studies should provide a comprehensive roles and tasks framework, especially when both parties, i.e., the BS practitioners and the non-allied construction professionals in the Malaysia are involved.

In line with the identified gaps, this paper seeks to remedy these problems by identifying the hierarchy and potential roles tasks that can be offered by the graduate building surveyors from the BS practitioners' perspective. To meet the objective that has been mentioned and to ensure a comprehensive data collection, this study has adopted a quantitative research approach involving a literature review and a closed-ended questionnaire for data collection, as well as descriptive statistics and inferential statistical analysis for analysing data.

\section{Literature Review}

The Malaysian construction industry is currently not only facing a new development as land is scarce, but is also facing re-development and major renovation on existing building and in the built environment. This increase volume of renewable projects runs parallel with the government's vision 2020 project which is aiming to boost the subsector construction projects in the next few years; this is supported by the government's plan to improve the country's transport network and tourism infrastructure and to increase the volume of renewable projects [8].

Therefore, a massive building control and building quality expertise are required in the postconstruction stage which involve the BS profession. This situation highlights the significance of establishing clear roles and tasks within the context of the Malaysia practice. Therefore, a detailed explanation of the literature reviews that focuses on international practice is beyond the domain of this article, hence, this article is mainly focused in complying with the issues in the Malaysia context.

\subsection{Scope of Services}

Competencies are an integral part of becoming a Registered Building Surveyor, and currently, the Royal Institution of Surveyors Malaysia (RISM) has issued a competency standard to define the ability for the surveying professionals in Malaysia to apply knowledge, skills attributes and judgment in their job with various competencies benchmarks. The RISM documentation highlights that there are two categories of competency, including core competency and optional competencies [9]. The guide presents building inspection and control as core competency and optional competencies, including building maintenance, building safety compliance and refurbishment management, and asset and facility management.

Technically, the main scope of work that is offered by the BS profession is building control and compliance as agreed by the Malaysian Qualifications Agency (MQA) Council. Meanwhile, the scope of services for other professionals such as Engineers, Architects, Quantity Surveyor, and Valuer, for instance, are building design, engineering/structure/infrastructure, cost and contract administration, and valuation or property services, respectively.

The RISM then presented the five primary services of a building surveyor, including building control administration, development and construction management, building works, building maintenance, and building insurance. These services 
are clearly stated in the 2021 BS Division, RISM's website. Furthermore, the Public Works Department (PWD), Ministry of Works Malaysia have also developed the Competency Model and Dictionary in 2012 with the aim of measuring and guiding PWD's employee's performance and their career growth [10]. The PWD documentation highlights that there are three technical competencies for building surveyors, including building inventory, building surveying, and building maintenance management.

In the United Kingdom (UK) practice, the primary role of building surveyors covers the six main areas consisting of building pathology, design, project management, building surveys, property management, and contract administration [4]. In addition, in order to become a competent building surveyor, an individual need to demonstrate knowledge, understanding and the practical ability that is relevant to a surveying role, which covers the seven core technical competencies, eleven mandatory competencies and seventeen optional competencies as listed in the Royal Institution of Chartered Surveyors (RICS) 2018 pathway requirement for building surveyors. There are building pathology, construction technology and environmental services, contract administration, design and specification, inspection, and legal or regulatory compliance that have been listed under technical competencies as the specific hard skills that are needed for the BS role [11].

However, the roles of this profession in Malaysia are limited and are not as widespread as what are being practised by the Chartered Building Surveyor in the UK. This statement is supported by [12] argument where they mention that the reason why so few building surveyors work outside the UK is because the BS work is being undertaken outside of the UK but presumably it is by other professionals. From the international employers' perspective, other factors that are affecting the complexity in the graduate building surveyors' employability is in part because the graduates do not meet the satisfactory competency level that is desired by the employer, the lack of publicity and awareness of surveying as a career, and a poor public image [13].

Although the belief that the RISM and PWD competencies should be used as a benchmark by the employers to develop their employees, a flexible approach to identify the niche area of the job for the graduate building surveyor should be used as it is vital to understand the current market on the building surveyor services and roles' demand by identifying the roles hierarchy that can be offered in the practice of a surveying discipline. However, previous studies in the BS field have not dealt with the scope of works or services framework in detail. [2] have agreed that few studies have explored the views and propositions of the stakeholders in the construction industry about building surveying.

Therefore, due to limited previous studies that have discussed the niche roles for BS in Malaysian practice and the absence of a BS Act which can be referenced, these scopes of services are only based upon the data that have been obtained from the various studies that have mentioned the roles and functions of building surveyors in Malaysia. Similar to other study designs, the research question for this study was therefore designed to achieve the research aim, 'What are the role acts that are expected to be performed and demonstrated by the Malaysian graduate building surveyor within the practice of a surveying discipline after graduation?' or 'What do entry-level building surveying do?'. Taking these research questions as the basis, the researchers began to conduct a preliminary research using a combination of the following terms: building surveyor and roles or Malaysian building surveying and roles practice.

Table 1. Summaries of Constructs and Items

\begin{tabular}{|l|c|c|c|c|c|c|}
\hline \multirow{2}{*}{$\begin{array}{l}\text { Potential } \\
\text { roles/services }\end{array}$} & \multicolumn{5}{|c|}{ Literature sources } & Total \\
\cline { 2 - 6 } & {$[14]$} & {$[15]$} & {$[16]$} & {$[17]$} & {$[10]$} & items \\
\hline $\begin{array}{l}\text { Building control } \\
\text { administration } \\
\text { (BCA) }\end{array}$ & $\mathrm{X}$ & $\mathrm{X}$ & $\mathrm{X}$ & $\mathrm{X}$ & & 14 \\
\hline $\begin{array}{l}\text { Building works and } \\
\text { quality (BWQ) }\end{array}$ & & & $\mathrm{X}$ & $\mathrm{X}$ & & 4 \\
\hline $\begin{array}{l}\text { Building inspection } \\
\text { (BI) }\end{array}$ & & $\mathrm{X}$ & $\mathrm{X}$ & $\mathrm{X}$ & 8 \\
\hline $\begin{array}{l}\text { Building } \\
\text { maintenance and } \\
\text { conservation } \\
\text { (BMC) }\end{array}$ & $\mathrm{X}$ & $\mathrm{X}$ & $\mathrm{X}$ & $\mathrm{X}$ & 13 \\
\hline $\begin{array}{l}\text { Building insurance } \\
\text { (BuI) }\end{array}$ & & $\mathrm{X}$ & $\mathrm{X}$ & & 6 \\
\hline $\begin{array}{l}\text { Risk management } \\
\text { and building audit } \\
\text { (RMBA) }\end{array}$ & $\mathrm{X}$ & $\mathrm{X}$ & $\mathrm{X}$ & $\mathrm{X}$ & 7 \\
\hline $\begin{array}{l}\text { Development and } \\
\text { construction } \\
\text { management } \\
\text { (DCM) }\end{array}$ & & & & & & \\
\hline \begin{tabular}{l} 
Seven constructs \\
\hline
\end{tabular} & & & & & 55 \\
\hline
\end{tabular}

The data were displayed in the schedule matrix table to identify pattern matching, as well as to compare and develop data network. The theme and sub-themes were identified through the coding (categories) process in order to establish categories for the roles and to sort the tasks into role categories. The filtering and reducing process was 
applied to highlight only significant data that contribute towards the results. Redundant constructs and elements were either combined or removed. Then, the count frequency of codes was deployed to prove codes with significant findings and codes with low findings. Based on the schedule matrix table, it is considered appropriate to consider any constructs that are recognised by more than two authors to be the major roles of the graduate building surveyors.

In regard to the literature review findings, the number of elements for the job tasks is 62 items with eight constructs or roles. However, only 57 items and seven constructs have been maintained following the experts' verification, i.e., the seven selected experts who are in the BS field. The review uncovered a total of seven roles of services as listed in Table 1. Next, a pilot test was performed to test the reliability and validity of the questionnaire [18]. Apart from being the best approach to eliminate any flaws and weaknesses of the survey instrument, the pilot study helped to fine-tune the instructions that are given to the respondents and ultimately in improving the overall structure and grammatical patterns of the questionnaire [19].

The result from the pilot test indicates that out of the 57 items, only 55 are considered valid to be used and therefore, are maintained. However, the results from the pilot study were not reported in this current research, because it is beyond the domain of this article. Notably, these scopes of services have been measured to gauge the need for BS graduates' services in the Malaysian construction industry, and to identify the potential roles and tasks that can be offered by the graduates.

\section{Methodology}

This study has adopted a quantitative method approach, in the actualisation of the research aims and objective, by means of a survey technique in order to study the potential services and hierarchical roles that can be offered by the building surveyor graduates. The advantage of the quantitative research design is the unbiased analysis of mathematical, numerical and statistical data that may be obtained through several means including the use of a well-structured questionnaire [20]. Notably, the merits of the survey research using questionnaire design are the possibility to collect a wide scope of information from a large population and the opportunity to deal with real situations [21].

\subsection{The sample}

The target population for this study involved registered members from the BS Division, RISM from academia, construction industry practice and government officer. In order to achieve this study's aim, a total number of registered and candidate members of the BS professions was obtained from the annual reports as provided by the RISM. Random/probability sampling design by means of the cluster sampling technique was adopted to select building surveyors who are registered as a member of the BS Division, RISM.

The cluster sampling was chosen due to the ability of the researchers to divide the sampling population into the groups without requiring a sampling frame [22], as provided by the RISM. From this sampling, since each cluster represents the entire population, therefore, more subjects can be included to be involved in the study. Based on the BS Division record in April 2021, there is a total of 1,157 building surveyor members within five classes of membership; the members consist of 19 Fellows, 206 Members, 189 Graduates, 62 Probationers, and 681 Student members [9]. However, only 476 respondents from Fellow and Member including the Malaysian Association of Registered Building Surveyor (MyRBS), Graduate, and Probationer classes were chosen as the sample in this research. Members from the Student class have been excluded so that the data that are gained are derived only from the experts.

A sample size and item calibration stability table that is based on the Rasch measurement model, as proposed by [23] has been adopted which yielded the targeted minimum population size of 100 respondents. This research expects to calibrate the item with $\pm 1 / 2$ logit and $95 \%$ confidence level, in which the minimum sample size range is $64-144$ and the size for most purposes is 100 .

Thus, a total of 476 samples is defined from the sampling frame and a minimum of 100 respondents are required as the sample size. As a final response were retrieved, a total of 136 building surveyors had participated in this study. Industry professionals and academicians from the building surveying field who were in attendance during the BS Continuing Professional Development (CPD) talk at the time were given the opportunity to participate in the study.

\subsection{Instrument}

The survey technique using a questionnaire was used to collect the data. The queries were addressed as closed-ended questions which required the respondents to rate their perception using a four- 
point Likert scale with a range of 1 (very unimportant) to 4 (very important); the use of the four-point Likert scale with or without a midpoint, according to [24], is considered acceptable and may not affect the reliability of the instrument. [25] found that a 6-point Likert scale (no midpoints) tends to give discriminating and reliability values that are higher than a 5-point scale with midpoints. This research instrument was designed to identify the hierarchy and potential roles that can be offered by $\mathrm{BS}$ graduates in order to provide the acceptable roles in the Malaysian construction industry. It is also being used to answered the research question that has been designed to achieve the research aim. The questionnaire contains two sections.

Section A queries the respondent's demographic background were obtained the respondents' academic qualification, organisation, position, year of working experience, and class of membership(s). Responses to these questions were used to describe in general terms the characteristics of the building surveyors who participated in the research. Descriptive statistics was used in order to summarize the respondent's demographic data in an organised manner by describing the trends and relationship between variables in a sample of population as suggested in [26] and [27].

Section B contains seven constructs with 55 items of the BS scope of works that has been adapted from previous studies, as shown in Table 1. This section is to identify the hierarchy and potential roles required from the BS graduates as perceived by the employers and industry. The questions were designed in the form of Likert's scale which required the respondent to rate the significance of roles ranging from 1 (very unimportant) to 4 (very important). The Rasch measurement model was applied to analyse the correlation of the variables in a role hierarchy.

\subsection{Data analysis}

[28] mention that it is essential to select a suitable test statistic technique that can be used along with the available information in carrying out the data test. The data analysis that is described here encompasses the quantitative data analysis techniques using statistical analysis consisting: 1 . descriptive statistics analysis, which summaries raw data from a sample or population and 2. inferential statistical analysis, which test the correlation of the variables and reach conclusions from the data.

Correctly, descriptive analysis was used to analyse the demographic profile data of respondents using IBM SPSS Statistics 23 and the data were presented in a percentage format and frequency.
Besides, inferential analysis was applied to determine the correlation of the variables in the research using the Rasch measurement model. The Rasch model can test the consistency of interpretation of constructs, the reliability of the items or person, and the accuracy of the test [29].

Apart from being a psychometric technique that is developed to improve the precision of construct instruments, monitor instrument quality, and to compute the respondents' performances [30], it has also provided a technique for obtaining an insight into how the data cooperate to construct measures [31]. This Rasch model is useful for converting raw observational data into item difficulty and person ability estimates on an approximately linear measurement scale [32]. Therefore, with the functionality of the Winsteps Windows-based software that assists many applications of the Rasch model, the data measurement that are involved in this study includes the reliability test, item fit test for content validity and item hierarchy.

Correspondingly, the reliability was measured on item reliability, person reliability and separation index. The reliability analysis was an important procedure to measure the degree of consistency of measurement and to test the survey scores that were free of measurement error [22][28][33][34]. Meanwhile, the content validity was measured by analysing the item fit test using infit and outfit items analysis. Validity analysis was a necessary procedure to test an instrument measure, i.e., what it is supposed to measure [28]. For content validity, the items have to cover a full range of the issue of the attitude that is being measured [24][34], which can be assessed using the item fit test with the help of the Rasch analysis. Item fit indicates the extent to which the response to a particular item is consistent with the way the sample respondents have responded to the other items [36].

Furthermore, the item hierarchy table was referred by assessing the item measure analysis in order to identify whether any items from the same construct measured the item's difficulty level at the same value or calibration [23]. Apart from being a test to measure the item's difficulty level, the item measure analysis is also used to identify the most agreed items or roles by the respondents that are to be included into the developed hierarchy. The further details and justifications of data analysis techniques, as discussed under result and discussion sub-topic. 


\section{Results and Findings}

\subsection{The Participant's Profile}

In this section, the descriptive statistics are used to present simple summaries about participants' profile in a manageable form using IBM SPSS Statistics 23. Section A of questionnaire form works to help construe the respondents' demographic profile. To fully obtain the profile of the respondents, this study had conducted frequency distributions of the participants' data; the respondents were from the building surveying and construction background with different fields of expertise (academia, government, and industry). The demographic data were obtained the respondents' academic qualification, organisation, position, year of working experience, and class of membership(s).

The largest group of respondents are the bachelor's degree holders $(64.7 \%) ; 29.4 \%$ are bachelor's degree graduates, and $5.9 \%$ are $\mathrm{PhD}$ holders. In terms of organisation characteristics, $50.0 \%$ of the respondents are industrial participants from the private sector, whereas $37.5 \%$ and $12.5 \%$ of the respondents are from the public sector and Higher Learning Institutions (HLIs), respectively. In terms of the post that is held by the respective respondents, $50.7 \%$ of the whole sample is building surveyor practitioners; $15.4 \%$ are lecturers; and $14.0 \%$ respondents hold other positions, e.g., assistant building surveyor, quantity surveyor, property manager, and site supervisor.

Meanwhile, $9.6 \%$ of the respondents are facilities managers; $3.7 \%$ are building managers and project managers, respectively, and the remaining $2.9 \%$ holds a construction management post. A further finding shows that most of the respondents have more than 12 years of working experience. Overall, the respondents' personal experience in the BS and construction industry is in the range of less than 3 years to more than 12 years, which provides a diverse spread of personal experience in this study. Based on the participants' background, this study has received quality information from a targeted source, i.e., people with extensive personal experiences who have the appropriate abilities in the BS industry.

Furthermore, the respondents who are participated for this study involved registered members from the BS Division that are mostly from academia, construction industry practice and government officer background, which represents the entire population, The targeted respondents from Fellow and Member including the Malaysian Association of Registered Building Surveyor (MyRBS), Graduate, and Probationer classes were chosen as the sample in this research, while Members from the Student class have been excluded so that the data that are gained are derived only from the experts.

\subsection{Reliability and Separation Index}

Reliability is a measure of the internal consistency of a set of scale items [37], which aims to minimise the errors and biases in measurements. [38] have suggested that the reliability coefficient ranges that are to be obtained is between 0 to 1 . Previous studies have explained that a Cronbach's alpha can take a value between 0 and 1 , which means that the closer the value is to 1 , the more reliable the scale of a variable and instrument [33][34]. Table 2 shows the reliability and separation index as ranked by the various group of respondents. The Cronbach's alpha value for all the variables is 0.91 , thus indicating a low error variance with a small measurement error. The value also indicates that the instrument that has been used has a high level of consistency [34][35], and that the instrument is acceptable to be used for identifying the potential roles.

In terms of the scale that is used, a number of important columns need to be considered, namely, the person's and items reliability and the separation index. As shown in Table 2, the value of the person's reliability is considered acceptable (0.90), which indicates that the respondents are the right persons for the query. Therefore, the instrument can differentiate a person's ability in identifying the potential roles and tasks. A further look at Table 2 shows that the item reliability that has been obtained is also considerably good (0.82); this indicates that the instrument is sufficient and has good reliability in measuring what it needs to measure [39].

Subsequently, the accepted strata separation value for both person and item should exceed 2.0 [36][37]. A higher value of separation indicates a greater spread of items and person along with a continuum [36][37]. In this case, the person strata separation is used to classify people while item separation indicates the separation of the item's difficulty level [42]. As illustrated in Table 2, the separation value of the person is 3.04 (rounded to 3.0). It indicates that the sample of 136 respondents can be separated into three requirement groups. This is considerably good as the higher values of separation indicate the greater spread of items and person along a continuum [36][37].

Meanwhile, the number of item strata separation is $2.0(2.10)$, which indicates that the items separation value is considered fair and can be separated into two difficulty levels. Based on the reliability and separation index results as has been 
discussed above, it can be concluded that the instrument that has been developed for the study is appropriate and reliable for measuring the potential roles that can be offered by the building surveyor graduating in Malaysia.

Table 2. Item and person reliability

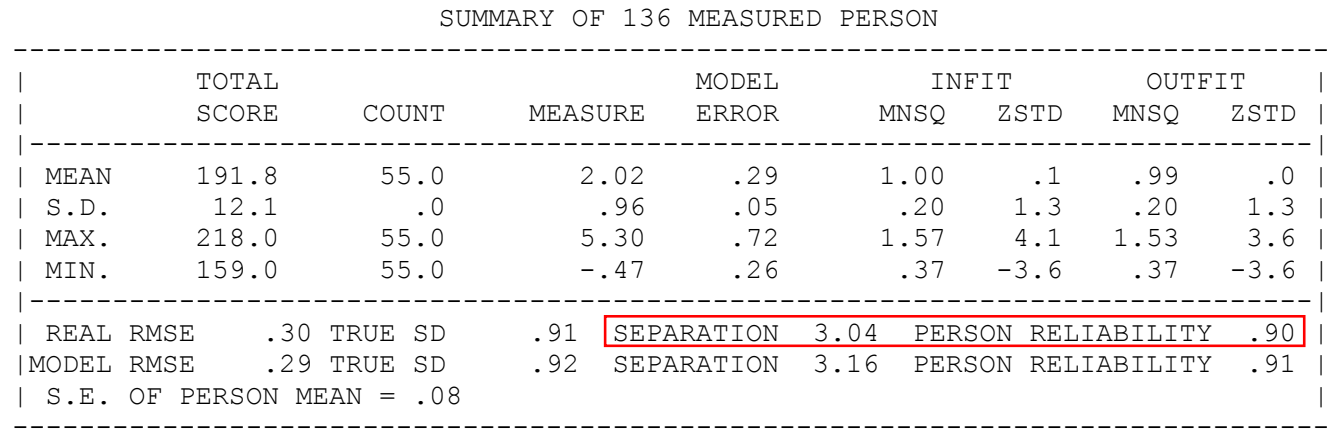

PERSON RAW SCORE-TO-MEASURE CORRELATION $=.99$ CRONBACH ALPHA (KR-20) PERSON RAW SCORE "TEST" RELIABILITY =.91

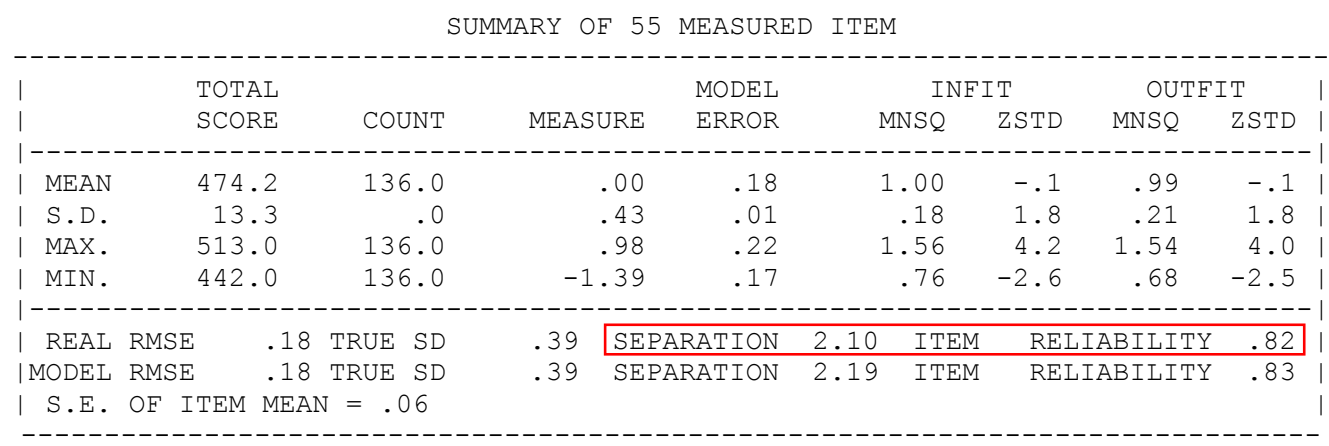

\subsection{Item Fit on Roles Hierarchy}

The 55 roles items that were identified from the literature were future subjected to item fit analysis by referring to the item measure table (Table 3). The fit statistics provide the indices of fit of the data to the model and usefulness of the measure [43]. In this context, item fit is an index of whether the items function logically and provide a continuum that is useful for all the respondents [43]. To determine which items fit the Rasch measurement model, a three-step criterion procedure needs to be performed starting with the attributes point-measure correlation (PTMEA Corr), followed by mean square (MNSQ), and finally, a z-standard (ZSTD) misfit pattern. In assessing the misfit data, the following guidelines are referred: 1. Investigate Outfit before Infit, 2 . Investigate MNSQ before ZSTD, and 3. Investigate the positive value of PTMEA Corr before the negative value [36][40][41][42].

First, by referring to the item polarity analysis, the construct validity can be further tested in determining whether the items are aligned in the same direction as the latent variable, and to find a correlation coefficient of the measurement-point, which is known as the PTMEA Corr value [42]. The
PTMEA Corr value was assessed to identify whether the item had been able to differentiate the ability of the respondents. The positive value of PTMEA Corr was determined as the indicator for the construct to be valid [44], while a negative value or zero indicates that the relationships for the response item or person contradict with the variable [31]. During the check, the PTMEA Corr value must be within the range of $0.2<$ PTMEA Corr $<0.79$, as suggested by the [31][40].

Secondly, further assessment was done by assessing the infit and outfit column for the MNSQ value. The infit and outfit mean square fit statistics indicate the degree to which an item functions as intended [39]. However, the outfit statistics scores are more sensitive to outliers [45], which means that an infit is less sensitive than an outfit to extreme responses [43]. Therefore, during the check, the outfit value of MNSQ must be in the range of $0.5<\mathrm{MNSQ}<1.5$, and $-2.0<\mathrm{ZSTD}<+2.0 \quad$ logit. Besides, if the outfit MNSQ is accepted, the ZSTD index can be ignored [40].

From the communalities table that is shown in Table 3, the correlation values for all 55 items are positive, and no negative correlation has been 
found. This result proves that the items have the capability of differentiating the respondents' ability, and that the items measure the constructs that are to be measured [44]. However, during a further check, the PTMEA Corr values for items B108, BCA10, BCA11, BCA12, BCA13, BCA14, and BMC04 have resulted in a low positive point-measure correlation value between 0.02 and 0.60 , which is below the range of $0.2<$ PTMEA Corr $<0.79$. These values indicated that the capability of these seven items was only weakly correlated with an increasing person's ability estimate [46]. However, considering [44] suggestion, as long as the correlation value is associated with the positive PTMea Corr value, the seven items can be considered to remain.

Further analysis was performed on the outfit MNSQ value and outfit ZSTD logit. Table 3 shows that at least 16 items are not in the specific range of value; they should either be purified or deleted. As a result, there are two illustrated information as shown in Table 3. First, item BI05 and item BI08 are outside the range of outfit MNSQ and ZSTD values, which either indicate that the misfit is far from the ideal model or does not include the pattern of responses [47]. Second, there are 14 items with an outfit ZSTD value of larger than the standard range of \pm 2 logit. The mentioned items are items BCA08, BCA10, BCA11, BCA12, BCA13, BCA14, $\mathrm{BMC04,} \mathrm{BMC07,} \mathrm{BMC10,} \mathrm{BMC11,} \mathrm{BMC} 12$, BMC13, BuI02, and DCM02.

However, these groups of items still fulfill the outfit MNSQ values and therefore, are acceptable to remain. As has been noted by [40], if the infit and outfit MNSQ values are accepted, the ZSTD value can be ignored. Therefore, based on the results, out of the 16 items, 14 variables will be retained and only two variables, item $\mathrm{BI} 05$ and item BI08, are found to be a misfit with the aforementioned MNSQ and ZSTD guidelines that are not contributing to the overall consistency. Through this, the two factors, $\mathrm{BI} 05$ and $\mathrm{BI} 08$ from the Building Inspection construct, have been removed from further analysis as they do not discriminate well, have double meaning, or provide redundant information.

Table 3. Item fit order and Item Hierarchy

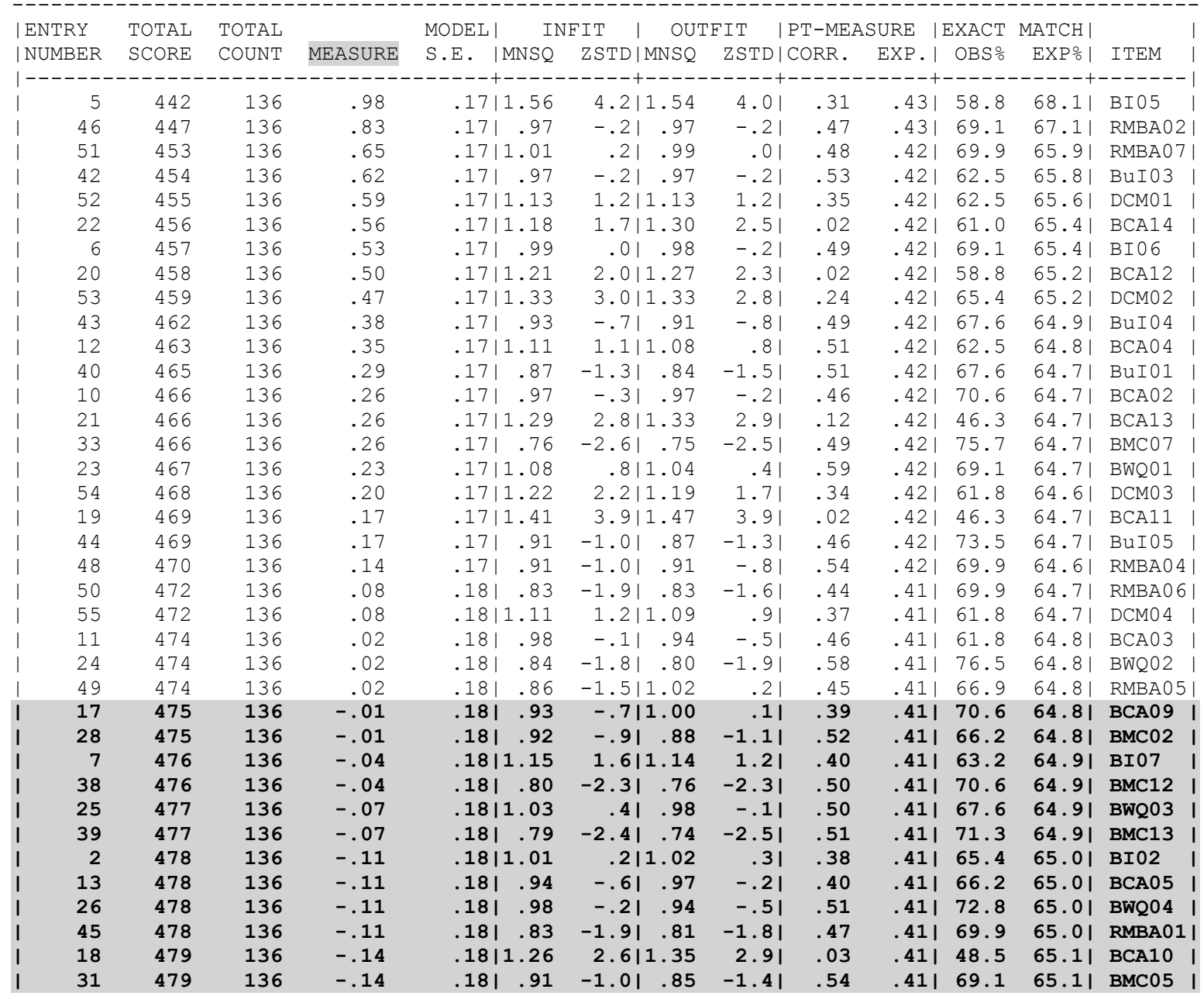




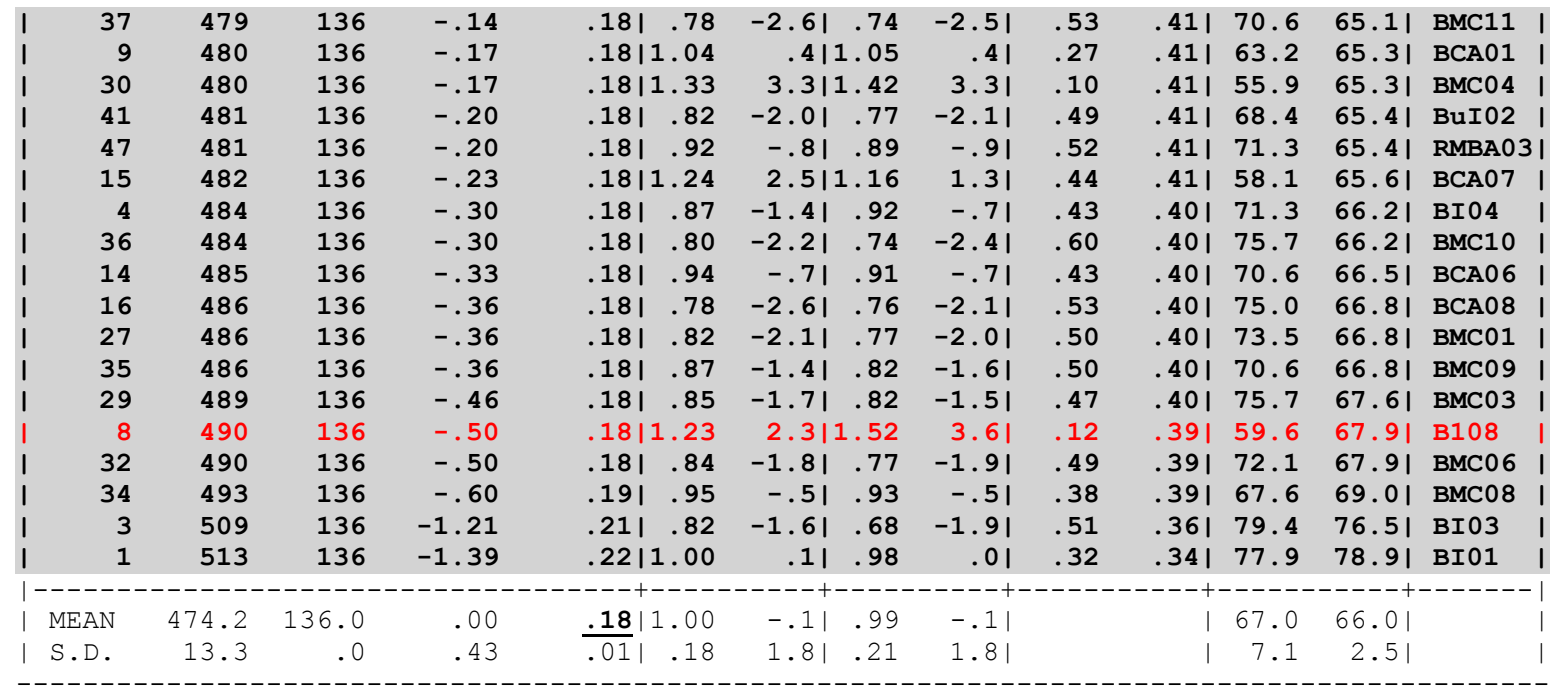

\subsection{Roles Hierarchy for BS Graduates}

[48] have explained that an item hierarchy is essential for categorising items into the strata of difficulty level. Item hierarchy was referred to as identifying: 1. the items (roles) most frequently agreed by the respondents, 2 . the items on an interval scale, and 3 . the potential inadequacies in a given scale [49]. Thus, the item measure table as shown in Table 3 was further referred to in order to identify the most agreed roles that were indicated by the respondents to be included into the hierarchy's roles. The most difficult items for the principals to agree with are above the item mean (.00), while the least difficult item for the principals to agree with were items with a negative logit [50].

Subsequently, Table 3 displays the items in the order of from the worst to the best fitting, i.e., from the hardest items to the easiest items to be agreed upon. The items that are the easiest to endorse fall towards the bottom of the hierarchy with a negative value, while the items that are the most difficult to endorse (positive value) are represented towards the top of the item hierarchy. These principles align with the study by [44]. Also, data in Table 3 shows that every item has a small measurement error (mean of SE +0.18 logit). The spread of the logit scale shows that the maximum item measure value is +0.98 logit (BI05-Building Inspection), and the minimum value is at -1.39 logit (BI01-Building Inspection). Therefore, the total of ruler length is 2.37 logit. This indicates that the difference between logit maximum and the logit minimum is located at $\delta=2.37$, where the item difficulty of the item is spread over 2.37 logit unit.

Hence, item BI05 has been allocated as the most difficult item to be agreed in terms of importance, while item BI01 is the easiest item to be agreed in terms of importance. A more critical look at Table 3 shows that about 25 items are above the item mean (positive value), which can be considered as not important items for the roles hierarchy [44]. Meanwhile, about 30 items that are recorded with negative values, which are recognised as the important items to be included in the hierarchy. However, out of the 30 items, item BI08 is considered to be removed because it does not fulfil the minimum criteria of MNSQ and ZSTD value as is recommended by [40].

More so, based on item fit analysis, there are two misfit items: item BI05 and item B108. [51] opined that the mistfit items that measure a different construct in the instrument should be revised or eliminated. This further indicates consistency in the decision to withdrawn item BI08 from the roles' hierarchy list. Based on the adequately discussed Rasch analysis, a roles' hierarchy has been generated in order to highlight the niche roles and services that BS graduates are required to perform in the construction industry after graduation. The results have produced 29 items with six area of services that are fit to be included in the roles of hierarchy for BS graduates, as shown in Table 4.

Table 4. Roles hierarchy of BS graduates

\begin{tabular}{|c|l|c|}
\hline Rank & \multicolumn{1}{|c|}{ Roles and Tasks } & $\begin{array}{c}\text { Item } \\
\text { measure }\end{array}$ \\
\hline 1 & $\begin{array}{l}\text { Carry out dilapidation survey or } \\
\text { pre-construction condition survey } \\
\text { of existing buildings }\end{array}$ & -1.39 \\
\hline 2 & $\begin{array}{l}\text { Identify cause of defects in } \\
\text { buildings, provide remedial } \\
\text { measures and give an evaluation } \\
\text { of the costs of repair }\end{array}$ & -1.21 \\
\hline 3 & $\begin{array}{l}\text { Assist in providing advice on } \\
\text { defect-free design, ways to reduce } \\
\text { maintenance problems and } \\
\text { prolong building lifespan }\end{array}$ & -.60 \\
\hline
\end{tabular}




\begin{tabular}{|c|c|c|}
\hline $\begin{array}{c}4 \\
\text { BMС06 }\end{array}$ & $\begin{array}{l}\text { Assist in providing advice and } \\
\text { prepare reports on building } \\
\text { maintenance }\end{array}$ & -.50 \\
\hline $\begin{array}{c}5 \\
\text { BMC03 }\end{array}$ & $\begin{array}{l}\text { Plan, coordinate and monitor the } \\
\text { scope of works for building } \\
\text { maintenance and management in } \\
\text { the Local Authority (LA) area }\end{array}$ & -.46 \\
\hline $\begin{array}{c}6 \\
\text { BMC09 }\end{array}$ & $\begin{array}{l}\text { Carry out the comprehensive } \\
\text { inspection to determine an } \\
\text { appropriate and a minimum cost } \\
\text { estimate on building inspection }\end{array}$ & -.36 \\
\hline $\begin{array}{c}7 \\
\text { BMC01 }\end{array}$ & $\begin{array}{l}\text { Inspect, report and prepare } \\
\text { programmes for implementing } \\
\text { maintenance management, } \\
\text { facilities and refurbishment work } \\
\text { of building }\end{array}$ & -.36 \\
\hline $\begin{array}{c}8 \\
\text { BCA08 }\end{array}$ & $\begin{array}{l}\text { Maintain and improve building } \\
\text { legislation and procedures set by } \\
\text { Government/Local Authorities }\end{array}$ & -.36 \\
\hline $\begin{array}{c}9 \\
\text { BCA06 }\end{array}$ & $\begin{array}{l}\text { Inspect and report on dilapidated } \\
\text { or unsafe old buildings, and } \\
\text { recommend the remedial actions } \\
\text { and expert evidence }\end{array}$ & -.33 \\
\hline $\begin{array}{c}10 \\
\text { BMC10 }\end{array}$ & $\begin{array}{l}\text { Carry out building audits and } \\
\text { provide the complete building } \\
\text { records and ensure it can be used } \\
\text { through the building audit system }\end{array}$ & -.30 \\
\hline $\begin{array}{c}11 \\
\text { BI04 }\end{array}$ & $\begin{array}{l}\text { Assist in providing advice on } \\
\text { refurbishment, conservation, fire } \\
\text { protection and means of escape }\end{array}$ & -.30 \\
\hline $\begin{array}{c}12 \\
\text { BCA07 }\end{array}$ & $\begin{array}{l}\text { Attend meetings and negotiations } \\
\text { related to the Uniform Building } \\
\text { Bylaws 1984, and the Road, } \\
\text { Drainage and Building Act } 1974 \\
\text { for construction works }\end{array}$ & -.23 \\
\hline $\begin{array}{c}13 \\
\text { RMBA03 }\end{array}$ & $\begin{array}{l}\text { Plan, inspect and carry out } \\
\text { building audits to identify space } \\
\text { quality and usage, asset inventory } \\
\text { and performance of building } \\
\text { elements }\end{array}$ & -.20 \\
\hline $\begin{array}{c}14 \\
\text { BuI02 }\end{array}$ & $\begin{array}{l}\text { Carry out physical building } \\
\text { evaluation as to determine } \\
\text { suitable policy insurance coverage } \\
\text { for damage by natural disaster, } \\
\text { and for damage to buildings under } \\
\text { construction }\end{array}$ & -.20 \\
\hline $\begin{array}{c}15 \\
\text { BMC04 }\end{array}$ & $\begin{array}{l}\text { Monitor and control the illegal } \\
\text { building/works, issuance of notice } \\
\text { to attend the court hearings; if any }\end{array}$ & -.17 \\
\hline $\begin{array}{c}16 \\
\text { BCA01 }\end{array}$ & $\begin{array}{l}\text { Check the procedural } \\
\text { requirements of drawings and } \\
\text { buildings to ensure compliance } \\
\text { with bylaws and regulations }\end{array}$ & -.17 \\
\hline $\begin{array}{c}17 \\
\text { BMC11 }\end{array}$ & $\begin{array}{l}\text { Prepare and develop a manual of } \\
\text { work and planned asset } \\
\text { maintenance }\end{array}$ & -.14 \\
\hline $\begin{array}{c}18 \\
\text { BMC05 }\end{array}$ & $\begin{array}{l}\text { Plan, coordinate and implement } \\
\text { building conservation and } \\
\text { preservation of old/historical } \\
\text { building in the LA area }\end{array}$ & -.14 \\
\hline
\end{tabular}

\begin{tabular}{|c|c|c|}
\hline $\begin{array}{c}19 \\
\text { BCA10 }\end{array}$ & $\begin{array}{l}\text { Inspect all buildings under } \\
\text { construction and upon } \\
\text { completion, to ensure building } \\
\text { works fulfils the legislation set by } \\
\text { the government or the LA before } \\
\text { issuing the certificate of } \\
\text { completion and compliance, or } \\
\text { before the handover of the project }\end{array}$ & -.14 \\
\hline $\begin{array}{c}20 \\
\text { RMBA01 }\end{array}$ & $\begin{array}{l}\text { Inspect and prepare reports on } \\
\text { conditions of buildings, post- } \\
\text { occupancy evaluation of buildings } \\
\text { conditions and risk assessment }\end{array}$ & -.11 \\
\hline $\begin{array}{c}21 \\
\text { BWQ04 }\end{array}$ & $\begin{array}{l}\text { Carry out inspection works and } \\
\text { building auditing after the } \\
\text { building has been completed to } \\
\text { check the quality standard before } \\
\text { the handover of the project }\end{array}$ & -.11 \\
\hline $\begin{array}{c}22 \\
\text { BCA05 }\end{array}$ & $\begin{array}{l}\text { Receive, inspect and approve the } \\
\text { application for building } \\
\text { demolition works in accordance } \\
\text { with the guideline of building } \\
\text { demolition works/laws and take } \\
\text { action on those who violate the } \\
\text { related requirement }\end{array}$ & -.11 \\
\hline $\begin{array}{c}23 \\
\text { BI02 }\end{array}$ & $\begin{array}{l}\text { Carry out pre-purchase building } \\
\text { survey of building condition } \\
\text { through inspection and checking }\end{array}$ & -.11 \\
\hline $\begin{array}{c}24 \\
\text { BMC13 }\end{array}$ & $\begin{array}{l}\text { Prepare and develop an } \\
\text { integrated asset maintenance } \\
\text { program }\end{array}$ & -.07 \\
\hline $\begin{array}{c}25 \\
\text { BWQ03 }\end{array}$ & $\begin{array}{l}\text { Protect buildings from } \\
\text { deterioration and verify safety } \\
\text { standards to the minimum levels } \\
\text { required and comfort to the users }\end{array}$ & -.07 \\
\hline $\begin{array}{c}26 \\
\text { BMC12 }\end{array}$ & $\begin{array}{l}\text { Prepare a comprehensive cost } \\
\text { estimation for maintenance and } \\
\text { asset management for short, } \\
\text { medium-term and long-term }\end{array}$ & -.04 \\
\hline $\begin{array}{c}27 \\
\text { BI07 }\end{array}$ & $\begin{array}{l}\text { Carry out and assess building } \\
\text { inspection to ensure the level of } \\
\text { building performance, safety and } \\
\text { building condition, and give an } \\
\text { evaluation of the cost of } \\
\text { repair/replacement/ maintenance }\end{array}$ & -.04 \\
\hline $\begin{array}{c}28 \\
\text { BMC02 }\end{array}$ & $\begin{array}{l}\text { Implement planned maintenance } \\
\text { technology and stock audition of } \\
\text { government buildings and } \\
\text { quarters }\end{array}$ & -.01 \\
\hline $\begin{array}{c}29 \\
\text { BCA09 }\end{array}$ & $\begin{array}{l}\text { Check plans for all types of } \\
\text { building (new, old, re-constructed } \\
\text { and renovated) to ensure they } \\
\text { fulfil all the legislative } \\
\text { requirements and issuance of } \\
\text { building approval }\end{array}$ & -.01 \\
\hline \multicolumn{3}{|c|}{$\begin{array}{l}\text { Note: } \\
\text { 1. Building Maintenance and Conservation (BMC) } \\
\text { 2. Building Control Administration (BCA) } \\
\text { 3. Building Inspection (BI) } \\
\text { 4. Risk Management and Building Audit (RMBA) } \\
\text { 5. Building Works and Quality (BWQ) }\end{array}$} \\
\hline
\end{tabular}


Based on the findings as shown in Table 4, the first role group, Building Maintenance and Conservation, had a total agreement of $41 \%$ and had 12 task variables which included (BMC01, BMC02, $\mathrm{BMC} 03$, $\mathrm{BMC04}, \mathrm{BMC05}, \mathrm{BMC06}, \mathrm{BMC08}$, $\mathrm{BMC} 09, \mathrm{BMC10}, \mathrm{BMC11}, \mathrm{BMC12}$, and $\mathrm{BMC13)}$. This suggests that professionals acknowledge that graduates need to possess building maintenance and conservation knowledge and skills to thrive in the labour market after graduation. This role complements the RISM claims which have stated that one of the primary roles of building surveyors covers the maintenance and repair of the building, as well as refurbishment and restoration of old properties.

The second most important role identified was titled Building Control Administration, with a total agreement of $24 \%$. This role comprised of seven building control tasks which included items BCA01, BCA05, BCA06, BCA07, BCA08, BCA09, and BCA10. This role complements the MQA which have agreed that the main scope of work that is offered by the building surveyor is building control and compliance. Besides, only $18 \%$ of the items are listed as the third most important role which is titled Building Inspection and have five items that include $\mathrm{BI} 01, \mathrm{BI} 02, \mathrm{BI} 03, \mathrm{BI} 04$, and $\mathrm{BI} 07$. It is, therefore, essential for graduate building surveyors to clearly articulate this role during their practice in the world of work as it is one of the niche roles and services that can be performed after graduation.

Meanwhile, $7 \%$ of the task variables represent the role of Risk Management and Building Audit role (RMBA01, and RMBA03) and the Building Works and Quality role (BWQ03, and BWQ04), respectively. The roles that were related to management, audit and building quality were associated with physical development management, controlling of construction quality, and assessment of the physical building condition, which were the typical duties of a building surveyor [7].

Whereas, the remaining 3\% of the item is from the Building Insurance (BuI02) scope of work. Instead, no task items in the Development and Construction Management role were agreed by the respondents to be important, which had been realised as unfit to be included in the roles' hierarchy. This finding suggests that the professionals value of the Development and Construction Management role is not profoundly present as a service that can be offered by building surveyors in real practice.

This suggests that professionals acknowledge that graduates need to be trained more on these six listed roles, therefore, the education providers need to adjusting their academic courses with the demanded role as presented in the roles' hierarchy table (Table 4.). With the fact that modern technologies are getting involved in the most of human activities nowadays as claims by [52], BS graduates should able to deals with the latest digital construction technology and required equipment that are commonly used in carrying out surveying works. Instead, the findings extend prior work by reinforcing the roles' hierarchy for building surveyors graduating in Malaysia, which highlights the importance of BS services in the construction industry. Currently, there are no specific job scopes that can be claimed under the BS domain due to the absence of the BS Act. Developing roles' hierarchy is one of the possible approaches in overcoming the issues of low awareness of the importance of building surveyors in Malaysia.

\section{Discussion}

Establishing a specific roles hierarchy for BS graduates is an essential part of establishing the awareness level of the significance of BS services among the graduates, the general public and other construction stakeholders in Malaysia. Unclear roles and tasks would mean that the building surveyors graduating in Malaysia are performing their duties and roles without having a good understanding of the important services that can be offered in this industry. This statement complements [53] theory of competency, because it is believed that maximum performance will occur when the capability of a person is consistent to the job requirements and the organisation's environment.

Referring to the earlier literature findings, the scope and services are offered by the BS profession in Malaysia includes building control and compliance, risk control and building performance, development and construction management, building works, building maintenance and conservation, and building inspection. However, the results of this study show that the Development and Construction Management role do not lead to an important role to be performed by the building surveyor graduating in Malaysia. The results presented above suggest that out of the seven roles, 
there are six distinct roles which represent potential roles that are to be offered by the BS graduates.

Therefore, conclusively this paper produced a roles hierarchy for the graduates building surveyor in Malaysia practices. The findings provide insights for prospective students, graduates, and the public on the building surveyors' scope of works, with the aim to enhance the awareness on the importance of the building surveyors' roles in the Malaysian construction industry. In particular, this provided a significant guideline for BS graduates in determining the niche area of the BS services in order to be more adaptable to construction related work practices. The final roles and tasks that are described here encompass six potential roles with 29 tasks that can be offered by graduate building surveyors consisting of Building Maintenance and Conservation, Building Control Administration, Building Inspection, Risk Management and Building Audit, Building Works and Quality, and Building Insurance.

Generally, this paper also contributes to this critical line of inquiry by examining these potential roles in the entry-level employment context that can be applied by building surveyors who are graduating in Malaysia. The roles hierarchy that has been developed in this study are part of a growing effort towards new insight into the technical employability skills that are required by building surveyors graduating in Malaysia, especially for entry-level.

\section{Conclusion}

This study investigates the role that graduates should perform in order to prepare them for the world of work after graduation. The study contributes to the body of knowledge by discussing the potential roles that the BS graduates need to perform in the world of work after graduation in the Malaysian construction industry. Accordingly, this finding pays tribute to the increasing importance of the building surveyor's role. The study used a quantitative method approach that involves literature review and a close-ended questionnaire survey as the means of data collection as well as descriptive statistics and inferential statistical analysis to analysed the data on reliability, item fit, and item measure for roles hierarchy as a method of scrutinising data. Data was obtained from professionals within the BS field, from those in academia, government agencies representatives and the construction industry.

Subsequently, the respondents' profile data was analysed using some descriptive statistics with the assistance of IBM SPSS Statistic, which were presented in percentage and frequency format. Additionally, the cleaned data for the developed roles hierarchy were analysed using the inferential Rasch statistical analysis such as the reliability test, item fit test, and item measure hierarchy. The Rasch analysis was found to be an optimum technique in presenting valid data and monitoring the quality of an instrument in more meaningful ways.

Through the Rasch model analysis, this study has managed to identify the hierarchy and potential roles that can be offered by BS graduates in the Malaysian construction industry. Results from the Rasch analysis have revealed six clusters of roles Building Maintenance and Conservation, Building Control Administration, Building Inspection, Risk Management and Building Audit, Building Works and Quality, and Building Insurance. As apparent from the study, these six roles' services are broad and encompass other related scope of works that can be offered, performed and focused in the Malaysian construction and built environment industry.

The findings of this study are considered to be the most important and different from other published studies when it reveals a roles hierarchy that graduates are required to perform, and where it will provide awareness on the existence of the BS vocation among other construction professionals and general public in Malaysia. In contrary to previous studies, this research has tended to focus on the role hierarchy required for the BS graduates rather than general services and roles that was offered by the professional building surveyor in Malaysian construction industry.

Contrary to previous studies, the findings suggest that the essential roles that the professionals expect from the graduates reflect significant development in knowledge and skills in the six niche roles as have been demonstrated by the 29 tasks that are established from the inferential analysis using the Rasch model. This role hierarchy set to become a vital factor in graduates' career development. For instant, graduate building surveyors who show knowledge and skills that are in compliance with these six role clusters stand out in employment opportunities, as they highlight the graduate ability to align with the industrial working practices and to follow the current demanded roles. However, there is a requirement for undergraduate students to attain not only knowledge but there is also the need to demonstrate critical technical skills during the recruitment phases because significant pressures have gathered pace for universities to produce skilled graduates who are industry-ready.

While it is understandable that some of the graduates will be unable to secure a placement due 
to inadequate employment opportunities, however, graduate building surveyors (entry-level) should plan the direction of their expertise after graduation by understanding their roles, the degree of priority that is based on the hierarchy that has been found. This study will benefit the society especially for BS practitioners, learning provider and organisation by sharing of knowledge through the significant findings from this study. Significantly, the findings also offer promising acknowledgement towards significant services and specific job scope that can be offered by the building surveyor profession, despite the fact that much more effort is needed to enhance the awareness of the existence of the BS professionals among the general public and the construction practitioners. Therefore, it is suggested that the authorities take due care in enhancing the awareness level of the significance of the building surveyors' services either through the endorsement of the Building Surveying Act and professional recognition, or through creating more job opportunities for BS graduates.

Also, the findings amplify the call for universities to embark on a strategic educational approach by redefining the content of the academic courses in order to complement the demanded roles and to encourage a new paradigm shift in the BS practice and education. A holistic comparison between the university's supply and industry's demand could offer further insights for the education provider and the industry to deflate the size of graduate mismatch especially in the current unprecedented nature of the Covid-19 pandemic, which has seriously affected the condition of the Malaysian labour market. Furthermore, further research could investigate the niche of the scope of works that can be practiced by the Malaysian building surveyor profession, from the non-allied construction professionals' perspectives. This approach amplifies the call for the construction practitioner and general public to be aware of the roles and existence of the BS vocation in the Malaysian construction industry.

\section{References:}

[[1] Construction Industry Development Board, Construction Industry Transformation Programme (CITP) 2016-2020. Malaysia: Construction Industry Development Board (CIDB) Malaysia, 2016.

[2] Isnin, Z., Hisham,. S.S.D.B., Ramele, R., and Zawawi, E.M.A., Challenges to Building Surveyors from the perspectives of non surveyors," MATEC Web Conf., Vol. 66, 2016, doi: 10.1051/matecconf $/ 20166600097$.

[3] Che-ani, A. I., Tazilan, A. S. M., and Kosman, K. A., The development of a condition survey protocol matrix, Struct. Surv., Vol. 29, No. 1, 2011, pp. 35-45, doi: $10.1108 / 02630801111118395$.

[4] Royal Institution of Chartered Surveyors, The Chartered Building Surveyor's portfolio, Royal Institution of Chartered Surveyors, United Kingdom, 2008.

[5] Hoxley, M., UK building surveying education: the graduates' view, Facilities, Vol. 30, No. 5/6, 2012, pp. 218-233.

[6] Ali, A. S., and Woon, C. J., Issues and challenges faced by building surveyors in Malaysia, Struct. Surv., Vol. 31, No. 1, 2013, pp. 35-42, doi: 10.1108/02630801311304404.

[7] Ali, A. S., and Woon, C. J., Training and development of Building Surveyors in Malaysia, RICS COBRA, 2012, pp. 777-785.

[8] Ministry of Entrepreneur Development and Cooperatives, Property Industry Outlook: Vendor Development Program, UDA, UEM Group and Sime Darby Property, Malaysia, 2020.

[9] Royal Institution of Surveyors Malaysia, Building Surveing Division: Annual Report for session 2020/2021, 2021.

[10] Public Works Department, Competency model \& dictionary: Jabatan Kerja Raya Malaysia Kumpulan pengurusan dan profesional skim perkhidmatan kejuruteraan (J), Revision 1, Jabatan Kerja Raya Malaysia, 2017.

[11] Royal Institution of Chartered Surveyors, RICS Pathway guide Building Surveying, United Kingdom, 2018.

[12] Kibblewhite, T., and Wilkinson, S., Building Surveying: A UK Phenomenon or a Profession with Genuine Global Appeal?, FIG Work. Week 2004, 2004, pp. 1-10.

[13] Wilkinson, S., and Hoxley, M., The impact of RICS education reforms on building surveying, Struct. Surv., Vol. 23, No. 5, 2005, pp. 359370, doi: 10.1108/02630800510635100.

[14] Che-Ani, A. I., The roles and involvement of building surveyors in the Malaysian building industry, Royal Institution of Surveyors Malaysia (RISM), Malaysia, 2013, pp. 1-23.

[15] Malaysian Qualifications Agency, Programme standards: Building surveying, Malaysian Qualifications Agency (MQA), Malaysia, 2013.

[16] Ramly, A. Kepentingan dan peranan Juruukur Bangunan dalam industri bangunan dan pembinaan di Malaysia, Institution of 
Surveyors Malaysia, Malaysia, 2003.

[17] Royal Institution of Surveyors Malaysia, Deskripsi Tugas Juruukur Bangunan, Royal Institution of Surveyors Malaysia (RISM), Malaysia, 2017.

[18] Khoiry, M. A., Hamzah, N., Wan Badaruzzaman, W. H., and Mohd Tawil, N., Reliability \& Validity of the Construction Delay Questionaire using the Rasch Mesurement Model, J. Kejuruter., Vol. 29, No. 1, 2017, pp. 13-21, doi: 10.17576/jkukm-201729(1)-03.

[19] Aliu, J., and Aigbavboa, C., Key generic skills for employability of built environment graduates, Int. J. Constr. Manag., 2021, pp. 119, doi: 10.1080/15623599.2021.1894633.

[20] Sukamolson, S., Fundamentals of quantitative research, Lang. Inst. Chulalongkorn Univ., Vol. 1, No. 2/3, 2007, p. 20.

[21] Fraenkel, J. R., and Wallen, N. E., How to Design and Evaluate Research in Education, $7^{\text {th }}$ ed. New York: McGraw-Hill Companies, Incorporated, 2008.

[22] Taylor, B., Sinha, G., and Ghoshal, T., Research methodology: A guide for researchers in management \& social sciences. New Delhi: PHI Learning Private Limited, 2009.

[23] Aziz, A.A., Masodi, M.S., and Zaharim, A., Asas Model Pengukuran Rasch: Pembentukan Skala \& Struktur Pengukuran, $1^{\text {st }}$ ed. Malaysia: Universiti Kebangsaan Malaysia, 2013.

[24] Tsang, K. K., The use of midpoint on Likert Scale: The implications for educational research, Hong Kong Teach. Cent. J., Vol. 11, 2012, pp. 121-130.

[25] Garland, R., The Mid-Point on a Rating Scale: Is it desirable?, Mark. Bull., Vol. 2, No. 3, 1991, pp. 66-70, doi: citeulike-articleid:4775464.

[26]Kaur, P., Stoltzfus, J., and Yellapu, V., Descriptive statistics, Int. J. Acad. Med., Vol. 4, No. 1, 2018, p. 60, doi: 10.4103/IJAM.IJAM 7 18.

[27] Loeb, S., Dynarski, S., McFarland, D., Morris, P., Reardon, S., and Reber, S., Descriptive analysis in education: A guide for researchers, Washington, DC: U.S., 2017.

[28] Manoharan, P. K., Research Methodology, $1^{\text {st }}$ ed. New Delhi: APH Publishing Corporation, 2009.

[29] Yasin, R. M., Yunus, F. A. N. , Rus, R. C., Ahmad, A., and Rahim, M. B., Validity and Reliability Learning Transfer Item Using Rasch Measurement Model, Procedia - Soc.
Behav. Sci., Vol. 204, 2015, pp. 212-217, doi: 10.1016/j.sbspro.2015.08.143.

[30] Boone, W. J., Rasch Analysis for Instrument Development: Why, When, and How?, Cell Biol. Educ., Vol. 15, No. 4, 2016, pp. 1-7, doi: 10.1187/cbe.16-04-0148.

[31] Linacre, J. M., Understanding Rasch measurement: Optimizing Rating Scale Category Effectiveness, J. Appl. Meas., Vol. 3, No. 1, 2002, pp. 85-106.

[32] Pelton, T., Where are the limits to the Rasch advantage?, in Proceedings of the International Objective Measurement Workshop (IOMW), 2002, pp. 1-34.

[33] Heale, R., and Twycross, A., Validity and reliability in quantitative studies, Evid. Based. Nurs., Vol. 18, No. 3, 2015, pp. 66-67, doi: 10.1136/eb-2015-102129.

[34] Muijs, D., Doing Quantitative Research in Education with SPSS, $2^{\text {nd }}$ ed. SAGE, 2011.

[35] Kumar, R., Research methodology: A step-bystep guide for beginners, $3^{\text {rd }}$ ed. London: SAGE Publications Ltd, 2011.

[36] Mccreary, L. L., Conrad, K. M., Conrad, K. J., Scott, C. K., Funk, R. R., and Dennis, M. L., Using the rasch measurement model in psychometric analysis of the family effectiveness measure, Nurs. Res., Vol. 62, No. 3, 2013, pp. 149-159, doi: 10.1097/NNR.0b013e31828eafe6.

[37] Yaacob, M. R, PASW (SPSS) Statistics 18: For Business and Social Science Students, 1st ed. Malaysia: Eduserve Resources, 2011.

[38] LoBiondo-Wood, G., and Haber, J., Nursing Research: Methods and Critical Appraisal for Evidence-Based Practice, $9^{\text {th }}$ ed. Elsevier Health Sciences, 2017.

[39] Wright, B.D. and Stone, M.H., Measurement Essentials, $2^{\text {nd }}$ ed. Wilmington, Delaware: Wide Range Inc, 1999.

[40] Linacre, J. M., A User's Guide to WINSTEPS/MINISTEP Rasch-Model Computer Programs (3.91.0). 2006.

[41] Fisher, W. P. J., Rating Scale Instrument Quality Criteria, Trans. Rasch Meas. SIG Am. Educ. Res. Assoc., Vol. 21, No. 1, 2007, p. 1095, doi: 1051-0796.

[42] Ariffin, S.R., Omar, B., Isa, A., and Sharif, S., Validity and reliability multiple intelligent item using rasch measurement model, Procedia Soc. Behav. Sci., Vol. 9, 2010, pp. 729-733, doi: 10.1016/j.sbspro.2010.12.225.

[43] Green, K. E., and Frantom, C. G., Survey development and validation with the Rasch model, in The International Conference on 
Questionnaire Development, Evaluation, and Testing, 2002, pp. 14-17.

[44] Bond, T.G., and Fox, C. M., Applying the Rasch Model: Fundamental Measurement in the Human Sciences, $2^{\text {nd }}$ ed. New Jersey, London: Lawrence Erlbaum Associates, 2007.

[45] Curtis, D.D., and Boman, P., X-ray your data with Rasch, Int. Educ. J., Vol. 8, No. 2, 2007, pp. 249-259.

[46] Miyata, M., A Rasch analysis of the ELI listening placement test., ScholarSpace, 2007.

[47] Aziz, A. A., Rasch Model Fundamentals: Scale Construct and Measurement Structure, $1^{\text {st }}$ ed. Advance Planning Sdn Bhd, 2010.

[48] Olojuolawe, S.R., Fadila, N.B.M.A., Latif, A.A., Sani, H.A., and Wase, H.G., Structural Classification of Employability Skills Hierarchy using Rasch Analysis Model, Int. J. Recent Technol. Eng., Vol. 8, No. 3, 2019, pp. 3581-3591, doi: 10.35940/ijrte.C5302.098319.

[49] Green, K. E., Applications of the Rasch model to evaluation of survey data quality, New Dir. Eval., Vol. 1996, No. 70, 1996, pp. 81-92, doi: 10.1002/ev.1036.

[50] Haryanti, M. A., Maat, S. M., Mohd Effendi, M. M., Mohd Firdaus, M. K., Khamis, A., and Adi Irfan, C. A., Construction management graduates roles and tasks portfolio: Analysing using rasch measurement model, Malaysian Constr. Res. J., Vol. 3, No. Special Issue 1, 2018, pp. 18-24.

[51] Othman, N., Mohd Salleh, S., Hussein, H., and Ab. Wahid, H., Assessing Construct Validity and Reliability of Competitiveness Scale Using Rasch Model Approach, in The 2014 WEI International Academic Conference Proceedings, 2014, pp. 113-120.

[52] Milkova, E., Chadimova, L., and Manenova, M., 3D technology in the cultural heritage and education context, Int. J. Educ. Inf. Technol., Vol. 13, 2019, pp. 59-64, doi: 10.1007/978-3030-21507-1_28.

[53] Boyatzis, R. E., The competent manager: A model for effective performance, Illustrate. New York: John Wiley \& Sons, 1982, 1982.

\section{Author Contributions:}

Siti Hamidah Husain was responsible for the conceptualisation of ideas and has implemented methodological approach.

Adi Irfan Che Ani and Haryanti Mohd Affandi was responsible for supervising of research activity planning execution and provision of study resources and material.
Afifuddin Husairi Hussain and Hasnizan Aksah was responsible for application of the Rasch analysis statistical to analyse study data.

\section{Sources of funding for research presented in a scientific article or scientific article itself}

This research was funded by Universiti Kebangsaan, grant number GGP-2019-001 and GGPM-2019-069.

\section{Creative Commons Attribution \\ License 4.0 (Attribution 4.0 International, CC BY 4.0)}

This article is published under the terms of the Creative Commons Attribution License 4.0 https://creativecommons.org/licenses/by/4.0/deed.en US 